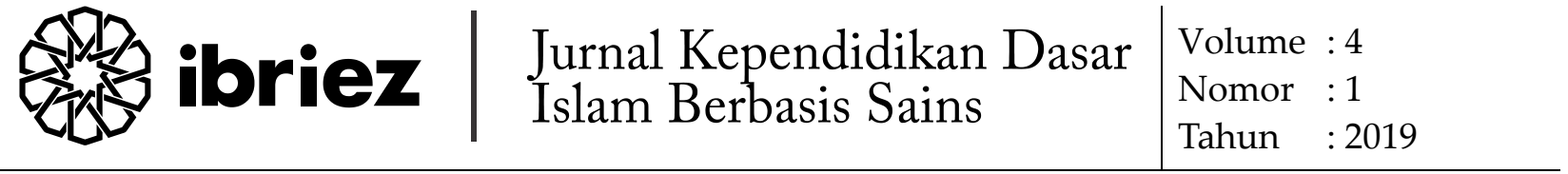

\section{Tindak Tutur Ilokusi dalam Percakapan Santri di Pondok Pesantren Mahasiswa Darussalam Surakarta}

\author{
Siti Aminataz Zuhriyah \\ Farida Yufarliana Rosita \\ Email : SitiAminatazZuhriyah@gmail.com \\ Institut Agama Islam Negeri Surakarta
}

\begin{abstract}
The research entitled "Illocutionary Speech of Santri Conversations at the Surakarta Darussalam Islamic Boarding School: Pragmatic Study" aims to describe or analyze the illocutionary forms used by students in interacting at the Darussalam Darussalam Islamic Boarding School. The method used in this study is a pragmatic qualitative method. This method is a research method that seeks to describe the meaning of speech in a community according to the object of the actual situation. The results of this study indicate that in interacting, between santri one and the other there is an illocutionary form that intersects the language used by students in the Darussalam Islamic Boarding School.
\end{abstract}

Keywords: illocutionary speech acts, Santri, Pragmatict, and Islamic Boarding School.

\begin{abstract}
Abstrak
Penelitian yang berjudul "Tindak tutur Ilokusi Percakapan Santri di Pondok Pesantren Mahasiswa Darussalam Surakarta: Kajian Pragmatik" bertujuan untuk mendeskripsikan atau menganalisis wujud ilokusi yang digunakan santri dalam berinteraksi di Pondok Pesantren Mahasiswa Darussalam. Metode yang digunakan dalam penelitian ini adalah metode kualitatif pragmatis. Metode ini merupakan metode penelitian yang berusaha menggambarkan makna tuturan pada suatu komunitas sesuai dengan objek keadaan yang sebenarnya. Hasil penelitian ini menunjukkan bahwa dalam berinteraksi, antara santri satu dengan yang lainnya terdapat wujud ilokusi menyimpangan bahasa yang digunakan santri di Pondok Pesantren Mahasiswa Darussalam.
\end{abstract}

Kata Kunci : Tindak tutur Ilokusi, Santri,Pragmatik dan Pondok Pesantren.

\section{A. Pendahuluan}

Pondok pesantren merupakan lembaga pendidikan Islam dengan tradisi salaf atau tradisional. Di pondok pesantren terdapat pengajian kitab, bandongan, atau sorogan.
Dalam sebuah pondok pesantren diajarkan penguasan ilmuagama, kualitas ilmu umum, akhlak (moralitas), dan berbagai orientasi perjuangan, menghadapi kemajuan zaman. ${ }^{1}$

1 Jamal Ma'mur Asmani, Fiqh Sosial Kiai Sahal Mahfudh (Surabaya: Khalista, 2007), 7. 
Pesantren sebagai lembaga pendidikan mampu menyampaikan ilmu pengetahuan secara mendalam. Tradisi keilmuan pesantren dengan sejumlah perangkatnya, memberikan nuansa berbeda dengan tradisi di luar pesantren. Tradisi keilmuan yang kuat dalam pesantren memberikan bekal pada santri kelak setelah dinyatakan lulus memiliki kemampuan dalam menguasai kitab kuning (klasik), kemudian mendapat ijazah dari seorang kiai, untuk mengamalkan ilmunya di tengah-tengah masyarakat. $^{2}$ Dengan demikian, tentu ada wujud tindak tutur dalam komunikasi yang digunakan santri untuk menjalani proses pembelajaran di sebuah pesantren. Khususnya di Pondok Pesantren Mahasiswa Darussalam (PPMD) Surakarta. ${ }^{3}$

PPMD terletak di desa Pucangan, Kecamatan Kartasura, Kabupaten Sukoharjo, Jawa Tengah. Pondok pesantren tersebut berada di sekitar kampus IAIN Surakarta. Pada awalnya, PPMD didirikan oleh kampus IAIN Surakarta yang dikhususkan untuk mahasiswa jurusan Pendidikan Bahasa Arab (PBA) dengan tujuan membantu dan mempermudah mahasiswa PBA dalam berbahasa Arab. Namun, tiga tahun terakhir ini, PPMD telah bermetamorfosis menjadi pondok umum yang menerima santri dari semua jurusan. Sejak berdiri bahkan sampai beralih fungsi, PPMD dikenal sebagai pondok bahasa, yakni pondok yang menganjurkan santrinya menguasai dan menggunakan dua bahasa asing, yaitu bahasa Arab dan bahasa Inggris

\footnotetext{
2 Ahmad Shiddiq, "Tradisi Akademik Pesantren," TADRIS: Jurnal Pendidikan Islam 10, no. 2 (2015): 220.

3 Dwi Kurniasih and Siti Aminataz Zuhriyah, "Alih Kode Dan Campur Kode Pondok Pesantren Mahasiswa Darussalam," Indonesian Language Education and Literature 3, no. 1 (2017): 54.
}

dalam berkomunikasi di dalam maupun di luar pesantren. ${ }^{4}$

Pondok Pesantren Mahasiswa Darussalam Surakarta dipilih sebagai objek penelitian dengan beberapa alasan bahwa, PPMD ini merupakan satu-satunya pondok yang memiliki progam khusus keseharian menggunakan bahasa asing dan menjalin kerjasama dengan progam pengembangan dan pembinaan bahasa asing Institut Agama Islam Negeri (IAIN) Surakarta. Selain itu, PPMD merupakan pondok pesantren yang dikhususkan bagi santri putri, sehingga keseharian dan kebiasaan santri putri akan jauh berbeda dengan kebiasaan santri putra. Santri putri cenderung lebih suka berkomunikasi dengan jangka waktu yang lama. Latar belakang terciptanya wujud tindak tutur bahasa santri, salah satunya ditentukan oleh perbedaan daerah asal. Dengan demikian, akan banyak wujud tindak tutur ilokusi yang digunakan santri di PPMD Surakarta.

Penelitian ini difokuskan pada komunikasi tindak tutur bahasa santri di PPMD dengan menggunakan kajian pragmatik. Pragmatik adalah studi tentang hubungan yang melibatkan seseorang untuk saling memahami satu sama lain yang ada dalam pikiran mereka. ${ }^{5}$ Pragmatik adalah telaah mengenai, "hubungan tandatanda". Teori pragmatik menjelaskan alasan pemikiran dalam menyusun makna ujaran yang dimaksud penutur kepada lawan tutur. Pragmatik adalah telaah mengenai hubungan antara tuturan bahasa dengan konteks yang disandikan dalam struktur bahasa. ${ }^{6}$ Tindak tutur suatu

\footnotetext{
4 Kurniasih and Zuhriyah, "Alih Kode Dan Campur Kode Pondok Pesantren Mahasiswa Darussalam."

5 George Yule, Pragmatik (Yogyakarta: Pustaka Pelajar, 2006), 5-6.

6 Kuswoyo Kuswoyo, Pendekatan Pragmatik Dalam Pembelajaran Bahasa (Madiun, 2009), 215.
} 
komunikasi pada teori pragmatik salah satunya adalah ilokusi. Ilokusi merupakan suatu tuturan yang memberitahukan atau menginformasikan suatu hal tertentu dengan maksud atau tujuan lain. Ilokusi adalah penekanan komunikatif suatu tuturan yang membuat suatu pernyataan, tawaran, penjelasan atau maksud-maksud komunikatif lainnya. ${ }^{7}$

Searle dalam bukunya membagi tindak ilokusi menjadi lima yaitu: (1) representatif (2) direktif (3) komisif, (4) ekspresif dan (5) deklarasi. ${ }^{8}$ Perbedaan bahasa santri dalam menanggapi interaksi dengan santri yang lainnya memungkinkan terjadinya wujud tuturan Ilokusi. Ilokusi menjadi tuturan bahasa yang menentukan setiap maksud dari tuturan yang disampaikan oleh penutur kepada lawan tutur. Dengan demikian, maka ditemukan tindak tutur ilokusi santri dalam berinteraksi.

\section{B. Metodologi Penelitian}

Metode yang digunakan dalam penelitian ini adalah metode kualitatif pragmatis. Metode ini merupakan metode yang bermaksud menggambarkan makna tuturan pada suatu komunitas, sesuai objek keadaan yang sebenarnya. ${ }^{9}$ Peneliti mengamati, mendengar, dan melihat secara langsung komunikasi santri di PPMD. Perekaman tersebut dilakukan dengan menggunakan alat bantu perekam (ponsel). Perekaman dilakukan pada saat mengaji, sorogan kitab, roan, rapat, yasinan, kumpul pengurus, sharing, masak, diskusi,

\footnotetext{
7 Kuswoyo, 5-6.

8 John R Searle, Speech Act: An Essay in The Philosophy of Language (Cambridge: Cambridge University, 1969).

9 Khairana Adinda Ayu, "Tindak Tutur Ilokusi Dalam Dialog Film 'Aku, Kau, Dan Kua' Karya Monty Tiwa," (PhD Thesis, Universitas Diponegoro, 2017), 3.
}

yang terdiri dari beberapa orang secara berkelompok atau bergerombol.

Ada tiga tahapan dalam melaksanakan penelitian ini yaitu, proses mencari data, mengolah data, dan menyajikan data. Pada proses pencarian data, peneliti menggunakan cara merekam dengan menggunakan alat bantu rekam (ponsel) dan mendengarkan secara langsung percakapan santri pada saat melakukan kegiatan mengaji, sorogan kitab, roan, memasak, mencuci, menjemur, rapat, diskusi, atau kegiatan lain dari yang sifatnya bergerombol atau mengelompok di PPMD. Teknik selanjutnya adalah mengolah data yaitu dengan cara mentranskip atau menganalis data yang sama sesuai kebutuhan penelitian. Setelah dilakukan analisis data, data tersebut kemudian disimpulkan dan disajikan secara terperinci dalam bentuk laporan. ${ }^{10}$

\section{Hasil dan Pembahasan}

Berikut hasil penelitian tindak tutur ilokusi santri di PPMD menurut Teori Searle :

1. Ilokusi Representatif

Data (1)

Munna : Iki jodohe, dadi bar nikah kae ditinggal KKN. ( a)

(Ini jodohnya, setelah selesai menikah langsung ditinggal KKN)

Nikmah : Lha, kok mesakne men to.

(b)

(Kok, kasihan sekali ya)

Berdasarkan data di atas, penutur Munna bermaksud menuturkan penjelasan atau memberitahukan kepada lawan tutur Nikmah tentang suatu informasi terkait

\footnotetext{
10 Muhammad Ihsan, "Perilaku Berbahasa Di Pondok Pesantren Adlaniyah Kabupaten Plasaman Barat," Wacana Etnik 2, no. 1 (2011): 25.
} 
sahabatnya yang baru menikah beberapa bulan, tetapi sudah ditinggal KKN oleh pasangannya. Dengan demikian, data (1) pada tuturan (a) di atas merupakan tindak tutur ilokusi representatif menginformasikan sesuatu.

Data (2)

Ida : Opo sesok ngaji ustaz Besud?

(Apa besok mengaji ustaz Besud)

Aminah : Hiyo....hiyooo. Ustaz Besud ki gor malam iki karo ngko pajar (d)

(Iya.. Iya... Ustaz Besud ngajinya malam ini sama nanti subuh)

Berdasarkan data di atas penutur Ida bermaksud menuturkan pertanyaan jadwal ngaji Ustaz Besud kepada lawan tutur Aminah. Kemudian lawan tutur memberitahukan jadwal ngaji Ustaz Besud kepada penutur. Dengan demikian, data (2) pada tuturan (d) mengenai jadwal ngaji Ustad Besud merupakan tindak tutur ilokusi representatif.

Data (3)

Pio : Minum kalau di Jawa apa?

(Kata minum kalau di Jawa artinya apa?)

Nadia : kalau Minum kalau di daerah Jawa ya tetep Minum (f)

(Kalau arti kata minum di daerah Jawa artinya sama tetap minum)

Pio : Kalau di Sunda minum itu Cebok, hahahaha. (e)

(Kalau di Sunda Minum itu artinya Cebok, hahahaha)

Berdasarkan data di atas penutur Pio menuturkan pertanyaan arti minum di daerah Jawa kepada lawan tutur Nadia.
Kemudian lawan tutur menjelaskan arti pertanyaan tersebut kepada lawan tutur di daerahnya. Dengan demikian, data (3) pada tuturan (f) merupakan tindak tutur ilokusi representatif.

Data (4)

Ayu : Besok santri tingkat Ula 4 kataman akhirussanahnya menghafalkan kitab (g) (Besok santri tingkat Ula 4 wisuda katamanya menghafalkan kitab Taqrib

Mia : "Nggih Mbak."

( Iya, Mbak.")

Berdasarkan data di atas penutur Ayu bermaksud menuturkan informasi kepada lawan tutur Mia bahwa wisuda pondok santri tingkat Ula 4 adalah menghafalkan kitab Taqrib. Dengan demikian, data (4) pada tuturan (g) merupakan tindak tutur ilokusi representatif.

2. Ilokusi Direktif

Data (5)

Mimin : ya Allah, ampun ngantuk ya Allah (i)

(ya Allah. Jangan ngantuk ya Allah)

Febri : Mbak Mimin, Ayo tidur !!

(j)

(Mbak Mimin, ayo Tidur!)

Berdasarkan data di atas penutur Mimin bermaksud menuturkan keinginannya untuk tidur karena keadaannya yang sudah mengantuk. Kemudian lawan tuturnya Febri menanggapi untuk mengajak tidur. Dengan demikian, data (5) pada tuturan (j) merupakan tindak tutur ilokusi direktif.

Data (6)

Febri : Cara menentukannya gimana? (k) 
(Cara menentukannya bagaimana?)

Titi : Frekuensi distribusi itu nanti ini nanti diurutkan. Ini kan paling rendah ke paling tinggi. (l)

(Frekuensi distribusi itu nanti diurutkan. Dari yang paling rendah sampai tinggi.)

Berdasarkan data di atas penutur Febri bermaksud menuturkan tugas perkuliahan managemen bisnis kepada lawan tutur Titi. Penutur meminta pendapat lawan tutur terkait tugas perkuliahannya. Dengan demikian, data (6) pada tuturan (k) merupakan tindak tutur ilokusi direktif.

Data (7)

Ustaz : Ndang ngaji, ndang Rotibul Hadad (m)

(Segera mengaji, segera membaca Ratibul Hadad)

Umamah : Nggih tad, sendiko dawuh.(n) (Iya ustaz, siap melaksanakan)

Berdasarkan data di atas penutur Ustaz bermaksud menuturkan permintaan kepada lawan tutur Umamah untuk segera mempersiapkan ngaji sekaligus membaca bacaan Ratibul Hadad. Dengan demikian, data (7) pada tuturan (m) merupakan tindak tutur direktif.

Data (8)

Dewi : Dek, kowe sek nggoreng ro iris-iris yo. (o)

(Dek, kamu yang menggoreng sama racik-racik ya)

Hanif : Nggih mbak. (p)

(Iya mbak).

Berdasarkan data di atas penutur Dewi bermaksud menuturkan perintah kepada lawan tutur Hanif untuk menggoreng dan meracik-racik bumbu masakan sesuai bagiannya. Dengan demikian, data (8) pada tuturan (o) merupakan tindak tutur direktif.

3. Ilokusi Deklarasi

Data (9)

Lutvi : Kita itu tadi tu bingung, mau rapat ngumpulin barengbareng. Pada bisa kapan gitu

(q)

(Kita tadi bingung, mau mengajak rapat kapan bisa kumpul semuanya)

Aminah : Temenku nggak bisa kalau di Darussalam

(r)

(teman saya tidak bisa kumpul kalau di Darussalam)

Berdasarkan data di atas penutur Lutvi bermaksud menuturkan kegelisahanya untuk mengajak kumpul bersama kepada lawan tutur Aminah. Kemudian lawan tutur menuturkan bahwa temanya tidak bisa hadir jika tempatnya berada di Darussalam. Dengan demikian, data (9) pada tuturan ( $r$ ) merupakan tindak tutur deklarasi.

4. Ilokusi Ekspresif

Data (10)

UstazahNopi:Ayo, Aminah maju ngikrobi sek isim jumlah fikliah (s)

(Ayo, Aminah maju mengikrobi isim jumlah fikliah)

Aminah : Hah.... Aku mbak?? Waduh aku lali mbak... (t)

(Hah... saya mbak? Haduh saya lupa mbak..)

Berdasarkan datadiatas penuturUstazah Nopi bermaksud menuturkan perintah kepada lawan tutur Aminah untuk mengerjakan soal jumlah fikliah pada kitab. Kemudian lawan tutur Aminah menyatakan perasaan terkejutnya ketika 
ustazah Nopi memerintahkan maju mengerjakan soal kitab pada jumlah fikliah. Dengan demikian, data (10) pada tuturan (t) merupakan tindak tutur ekspresif.

Data (11)

Ailul : Iki sek urung balik pondok Sopo? Alfi kok urung balik pondok ki piye?

(Ini yang belum pulang pondok siapa? Alfi kok belum kembali ke pondok itu bagaimana?)

Umamah : Alfi, lul?? Izine pirang dino re? (v)

(Alfi Lul? Izinnya berapa hari memangnya?)

Berdasarkan data di atas penutur Ailul bermaksud menuturkan pertanyaan kepergian Alfi dari pondok pada lawan tutur Umamah dengan nada kalimat ekspresi menahan kemarahan. Dengan demikian, data (11) pada tuturan (u) merupakan tindak tutur ekspresif.

Data (12)

Azim : Hih kucingg, kenapa sih di sini? (w)

(Hihhhh... Kucing kenapa kamu di sini?)

Aik : Cuhhh...Cuhhh sini

(mengarah pada kucing) (x)

(Cuhhh... Cuh.... Sini

(mengarah pada kucing)

Berdasarkan data di atas penutur Azim bermaksud menuturkan perasaan jengkelnya terhadap kucing kepada lawan tutur Aik. Kemudian lawan tutur mengambil kucing tersebut agar penutur bisa mengurangi jengkelnya. Dengan demikian, data (12) pada tuturan (w) merupakan tindak tutur ekspresif.
5. Ilokusi Komisif

Data (13)

Aminah : Mbak, aku meh izin lungo. (y) (Mbak, aku mau izin pergi).

Novi : suwi opo ora? (z) (Lama atau tidak?)

Aminah : Engga kok mbak.

(y)

(Tidak mbak.)

Berdasarkan data diatas penutur Aminah bermaksud menuturkan keinginannya untuk izin keluar pondok kepada lawan tutur Novi. Kemudain lawan tutur menanyakan kepada penutur terkait lama tidaknya penutur bepergian. Selanjutnya penutur menjawab bahwa (y) tidak akan pergi dalam waktu lama. Dengan demikian, data (13) pada tuturan (y) merupakan tindak tutur komisif.

Berdasarkan data analisis di atas, dapat diketahui bahwa tindak tutur ilokusi yang paling sering digunakan santri dalam berinteraksi di PPMD meliputi : representatif, direktif, dan ekspresif. Representatif adalah tuturan memberitahukan atau menginformasikan suatu hal oleh penutur kepada lawan tutur. Bentuk ilokusi direktif adalah bentuk tuturan yang meminta atau mengajak lawan tutur untuk memperoleh sesuatu. Penutur menyampaikan permintaan untuk memperoleh sesuatu kepada lawan tutur. Penutur menginginkan sesuatu yang disampaikan kepada lawan tutur baik secara langsung ataupun tidak langsung dengan pernyataan. Ilokusi ekspresif adalah bentuk tuturan yang menyatakan perasaan penutur kepada lawan tutur, sehingga menimbulkan ekspresi wajah. 


\section{Penutup}

Berdasarkan pembahasan yang telah dipaparkan, penulis dapat menyimpulkan bahwa tindak tutur ilokusi dalam teori Searle dalam buku Pragmatik yang sering digunakan di Pondok Pesantren Mahasiswa Darussalam, yaitu (1) tindak tutur ilokusi representatif (menginformasikan), (2) tindak tutur ilokusi direktif (meminta), dan (3) tindak tutur ilokusi ekspresif (perasaan).

Tindak tutur ilokusi representatif adalah tindah tutur yang meliputi menginformasikan, atau memberitahukan tentang suatu hal yang dianggap perlu disampaikan kepada lawan tutur. Tindak tutur direktif meliputi meminta, mengajak, atau memerintahkan kepada lawan tutur. Tindak tutur ilokusi ekspresif meliputi tindak tutur yang menunjukkan perasaan dalam pengekspresian kondisi penutur kepada lawan tutur.

Dari simpulan tersebut dapat dikemukakan saran, yaitu pembaca yang tertarik dengan penelitian pragmatik seyogyanya mempelajari maupun memperdalam teori tindak tutur ilokusi. Peminat kajian pragmatik hendaknya mengkaji lebih dalam tentang berbagai kegiatan dan aktivitas tindak tutur, karena jenis tindak tutur sangat beragam yang cukup banyak. Penelitian lain yang akan melakukan penelitian mengenai tindak tutur ilokusi hendaknya memfokuskan tindak tutur ilokusi dengan objek penelitian yang berbeda dengan penelitian sebelumnya.

Semoga dengan adanya penelitian ini, dapat bermanfaat bagi penelitian dalam bidang yang sama untuk dijadikan rujukan teori. Penelitian ini diharapkan dapat meningkatkan pengetahuan pembaca khususnya dalam kajian pragmatik ilokusi tindak tutur.

\section{DAFTAR PUSTAKA}

Adinda Ayu, Khairana. "Tindak Tutur Ilokusi Dalam Dialog Film 'Aku, Kau, Dan Kua' Karya Monty Tiwa,." PhD Thesis, Universitas Diponegoro, 2017.

Asmani, Jamal Ma'mur. Fiqh Sosial Kiai Sahal Mahfudh. Surabaya: Khalista, 2007.

Ihsan, Muhammad. "Perilaku Berbahasa Di Pondok Pesantren Adlaniyah Kabupaten Plasaman Barat." Wacana Etnik 2, no. 1 (2011): 25-38.

Kurniasih, Dwi, and Siti Aminataz Zuhriyah. "Alih Kode Dan Campur Kode Pondok Pesantren Mahasiswa Darussalam." Indonesian Language Education and Literature 3, no. 1 (2017): 53-65.

Kuswoyo, Kuswoyo. Pendekatan Pragmatik Dalam Pembelajaran Bahasa. Madiun, 2009.

Searle, John R. Speech Act: An Essay in The Philosophy of Language. Cambridge: Cambridge University, 1969.

Shiddiq, Ahmad. "Tradisi Akademik Pesantren." TADRIS: Jurnal Pendidikan Islam 10, no. 2 (2015): 218-229.

Yule, George. Pragmatik. Yogyakarta: Pustaka Pelajar, 2006. 